In British Columbia, this reduction of our allowable annual cut due to withdrawal of forest lands ( $1.4 \%$ per year) is almost 10 times the reduction of the allowable annual cut due to lack of regeneration $(0.16 \%$ per year).

What is the answer? How can we offset these threats, and manage the forest to meet the needs of all users? Of course, finding that answer is the purpose of this symposium, but I am tempted to offer some suggestions.

We are now facing a massive timber shortage because, in general, governments have not been able or willing to provide funding for sound forest management. The short-term perspective of the politician and the even shorter-term fiscal policies of government do not permit government agencies to manage the forest properly on a site-specific basis. Just compare forest practices in most of Canada with the good forest practices in countries where much of the forest land is owned outright by the wood user. In Sweden, where there is greater growing stock now than ever before, only $25 \%$ is owned by the state. In British Columbia the province owns $95 \%$ of the forest land, and each year there is less growing stock.

In Canada, the areas of public forests that have been managed to an acceptable standard are in long-term tenures, such as tree farm licences in British Columbia, and similar tenures in Alberta and Nova Scotia.

By insisting that the wood user properly manage all values of the forest in return for a secure and consistent timber supply, and a funding formula to manage the forest on a long-term basis, we can meet the needs of all users.
To resolve the issue, and to implement effective management of all resources of the forest, in Canada we should:

1. Create forest management units and "lease" area(s) to the wood user for forest management on a long-term (25-year) tenure.

2. Treat costs of basic and intensive management as an operating cost and make provision for funding on a longterm basis. Management would include not only management in a silvicultural sense, but enhancement of wildlife, fish, recreation, and water quality. All this must be funded before the government creams off the "surplus" in the form of stumpage.

3. Integrate government jurisdictions so that forests, wildlife, fish and lands are administered under one minister and one deputy minister.

4. Define specific objectives and standards of performance for best mix of "products" from the forests - silviculture, log harvesting, fish and wildlife, recreation - and delegate full authority to the forest user to achieve the standards.

Then we shall achieve high standards of forest management - intensive forest practices, consideration of fish and wild life values based on nonemotional benefit/cost comparisons, balanced logging plans to achieve a consistent harvest of all forest values on a long-term basis. Part of this concept is already working in British Columbia. All that is required is to extend this concept to other forest disciplines, and throughout Canada.

\title{
Integrating Forestry and Wildlife Management: The View of the Private Land Timber Resource User
}

\author{
by
}

\author{
P.P. Hynard 1
}

\begin{abstract}
The users of the private land timber resource include the landowner (who uses it for property income), the logger, and the mills dependent on local timber supply.

The objectives of landowners vary considerably, as do their dependence on timber sales for income and their use of the property for personal recreation. Loggers tend to view forestry-wildlife integration unfavourably wherever this results in increased logging costs. The forestry interests of the local mills are similarly those of timber availability, wood procurement costs and freedom from disruption of supply.
\end{abstract}

Key words: Forest management, private forest lands, integrated land management, wildlife management.

\section{Who are the Timber Resource Users?}

The purpose of my paper is to represent the timber resource user's view on the integration of forestry and wildlife manage-

Management Forester, Ontario Ministry of National Resources, Minden, Ontario $\mathrm{KOM} 2 \mathrm{KO}$ ment on private lands. In reality there are several timber resource users: the landowner, who uses the timber resource for property income; the logger, who uses it for a livelihood, and the mills dependent on local timber supply.

I shall attempt to present each of their views separately, and follow this with a case study of Haliburton County, which is located to the immediate south of Algonquin Park in Ontario.

\section{The Landowners}

The objectives of landowners vary considerably. So do their use of the standing timber resource for income and their use of the property for personal recreation. There are exceptions, it seems, to all of the generalizations that follow.

Large tracts of land are often company- or corporationowned. In this case timber revenues may be important to the owner to pay for access development, land taxes, and other costs of holding land pending the development of lakeshore property or other speculative values. In some cases the land is held by a forest industry as a source of timber supply or as a last-resort supply reserve. It may even represent a sustained yield timber production unit, although this is unusual in eastern Canada.

Where lakeshore properties have already been developed and severed from the hinterland parcel or where no such potential exists, stumpage values may represent a high por- 
tion of the property value. Stumpage values may be used for conversion back to cash when required by the business interests of the owner. In some cases logging companies will purchase the property, cut the timber and subsequently resell the land. Once the marketable timber has been stripped from a property, often the only resale market is to private hunt clubs.

The rental of hunting and fishing access rights to outfitters or to private hunt clubs may represent a separate source of revenue and interest to the large landowners. If the main source of property income is from timber stumpage sales and if hunting and trapping leases represent a minor amount, the owner's view is rarely favourable to the integration of forestry and wildlife management. Sometimes, however, a property owner or manager has a public relations or personal wildlife interest, and this may temper the zeal with which forestry operations will overrun wildlife concerns

Small properties are more typically owned by individuals or by partnerships who purchased the land for their own use, often including hunting and enjoyment of nature. Because of their size these properties are able to provide only infrequent and usually low timber revenues. I have found resident owners to be more open to timber sales because of their greater familiarity with them, their lower income from other sources and, often, their relationship with a local logging contractor. Nonresident urban owners are less open to timber sales, it seems, because of a lower reliance on such revenues, a greater use of the property for personal recreation, and a greater distrust of forest exploitation.

On small holdings wildlife and recreational interests often outweigh timber interests. Hunt clubs and other landowners may refuse to permit timber harvesting on their land because they have seen the mess that logging has caused elsewhere. They simply don't want to risk the road damage, rutted skid trails and regrowth that can impede their travel and personal enjoyment of property. Moreover, nonresident owners may not understand how, or indeed be able, to control a harvesting operation. They may also not understand the potential for habitat improvement that logging can provide.

Small landowners, then, may view favourably the integration of forestry and wildlife management but only if they can be assured that their other property interests and values can be protected during the timber harvest.

\section{The Loggers}

Loggers are often made out to be the villains in the piece. In fact they are just small businessmen and entrepreneurs engaged in a physically demanding, cyclic and high risk business that offers a low profit margin, in an area with few employment alternatives. (They may also be a wildlife resource users with a few ideas of their own on the subject.)

Logging companies and contractors can acquire the cutting rights to private lands in several ways. These include outright purchase of the land, the purchase of timber rights for a specified period of time, the purchase of a specified timber stand or timber sale, or the sub-contract cutting of another's timber rights. Timber sales may be negotiated for payment based on mill scale or may be by tendered lump sum, cash up front. The agreements between logger and landowner may be comprehensive legal contracts complete with penalty clauses and performance deposits, or they may be based merely on vague verbal arrangements.

Timber rights that have been acquired are almost always exercised. Once their deals have been struck, loggers attempt to conduct their operations so as to maximize their profit margin. They are unlikely to do otherwise in the interests of a third party on a piece of land to which they may never return. This may be tempered somewhat to please an owner from whom a logger may desire further cutting rights. But usually the by-passing of merchantable timber or the alteration of an operation reduces yield and raises the costs of producing logs which, after all, sell for a fixed price.

Logging operations have the potential to affect wildlife and other property values adversely. Where these are of concern to the landowner, they must be specified in the agreement before financial negotiations are made. It is the landowner who pays for forestry-wildlife integration in the form of reduced timber revenues.

The logger, then, does not usually favour integration unless its provision is specified in agreement with the owner.

\section{The Dependent Mills}

Here we will assume that the dependent mill operators are neither landowners nor loggers, in which case their views would be as previously described. The timber resource interests of the dependent mills are essentially those of availability, wood procurement costs, and freedom from disruption of supply.

If the integration of forestry and wildlife interests were to reduce timber availability, the dependent mills would oppose it, especially if standing timber is locally in short supply. Such an integration, if implemented on a large scale, might also result in higher logging and log purchase costs. This would also draw opposition from mill operators. The view of the dependent mills, then, is generally unfavourable to the integration of forestry and wildlife management if the effect is to reduce timber availability, increase wood procurement costs or cause disruption of supply.

\section{A Common Denominator}

There appears to be a common denominator in the problem of forestry-wildlife integration on private lands and this is the general lack of knowledge amongst landowners, loggers, and mill managers of the effects of specific harvesting operations on the local wild life species. Usually when a wild life concern is expressed it is for a high-profile species, such as big game or a species considered endangered.

Commonly landowners, especially small landowners, feel concern for wildlife and wildlife habitat and oppose timber harvesting on their lands for this reason. They lack appreciation of the benefits that forest disturbances may provide to wildlife populations, indeed of their necessity for some species. Even where these factors are appreciated, the landowner may attempt to insist upon measures that are both unnecessary or useless to wildlife and excessively costly or restrictive to the logger. It is even more common for a logger to cut on a piece of land with no understanding of the effects that his operations will have on wildlife species. In some cases useful measures could have been easily instituted at little cost, had they been known.

Most provincial ministries responsible for natural resources provide extension services in the form of forestry advice. These are usually timber-oriented rather than wildlifeoriented, and even then may be limited in nature. In short, the landowner may be hard pressed to obtain sound direction in the integration of forestry and wildlife interests.

\section{Haliburton County: A Case Study}

Haliburton County is a 1658-sq.-mi. (4294-km²) municipality to the immediate south of Algonquin Park in Ontario; indeed a portion of the county falls within the park. The land is a rugged and broken piece of the Canadian Shield, thinly covered with till soils and forested with sugar maple, beech, and eastern hemlock in some areas and with mixures of aspen, white birch, red maple, white pine, and balsam fir in others. The land is $90 \%$ forested, the remainder being unim- 
proved pasture land or abandoned fields. Toronto is a threehour drive to the south.

The postwar cottage country era has seen the local economy evolve from total dependence on logging, sawmilling and agriculture to predominant reliance on the service sector Forestry, however, remains very important, indeed, it is the only manufacturing activity.

Hunting, especially big game hunting, though seasonal, is also important both as part of the traditional local life style and for the tourist dollars that it brings. The white-tailed deer is the principle big game species and is hunted by parties from hinterland camps using hounds and rifles. Moose and black bear also occur in huntable numbers. Ruffed grouse and ducks are the only small game species of any importance. The trapping of beaver, muskrat, raccoon, fox, fisher, marten, and mink for fur is also common in the area.

Two-thirds of the land is in private ownership. The remaining third is a corner of Algonquin Provincial Park and other Crown lands managed by the Ministry of Natural Resources. Much of the private land is in large single-ownership blocks, a pattern that resulted from the sale in 1861 of over 400000 acres (161000 ha) in fee simple to the Canada Land and Emigration Company. Twenty percent ${ }^{2}$ of the private land is held in blocks exceeding 1000 acres ( 405 ha), $14 \%$ in blocks between 300 and 1000 acres (121 and 405 ha) and $56 \%$ in parcels between 50 and 300 acres (20 and 121 ha).

Logging is especially active on the larger properties for sawlogs, fuelwood and pulpwood. Some $10 \%$ of the private lands are under forestry agreements with the provincial government for intensive forest management. A municipal tree cutting bylaw covers $25 \%$ of the county under which private land logging is regulated by diameter limits (unless otherwise prescribed by a registered professional forester). The bylaw also prohibits the logging of hemlock within the 7000 acre ( 2800 ha) Percy Lake deer yard. The remainder of the operations receive little or no silvicultural or wildlife consideration before the cut.

The harvesting operations tend to be broken up by the terrain, the variety of stand conditons and by the land ownership pattern. This produces, for the most part, dispersed operations of a variable intensity and extent. There are large cuts and small, clearcuts and various intensities of partial cuts. In general, the nature of the local cutting practices greatly benefit wildlife populations by providing diverse food sources at ground level throughout the county on a continuing basis.

A maple clearcut or near clearcut for example, will produce maple regeneration and herbacious (skid-trail) growth upon which mice and rabbits feed, raspberry cane for autumn deer browse, blackberries and raspberries for summer bear feed, pin cherry for winter grouse budding, maple regeneration for áutumn and winter moose browse and, of course, prey for raptors and fur-bearing predators (to mention but a few). If the cut is of modest size (the usual case) then cover, den trees and other habitat will be nearby.
It is the white-tailed deer herd that is vulnerable to habitat deterioration caused by forestry operations. In the early winter the herd migrates to several major, traditional yarding areas and to other small ones. These are mainly areas of hemlock and maple in which the hardwoods provide winter browse and the conifer provides cover and reduced snow accumulation. The maintenance of conifer cover in traditional yards is critical to the survival of the herd in this area where snow depths can otherwise reach $3 \mathrm{ft}$. $(90 \mathrm{~cm})$ or more and where winter rains can otherwise build surface crusts that support wolves and coyotes but further hamper deer. The second-largest of these yards, the Percy Lake yard, is in private ownership, shared by four landowners.

The hemlock occur in old-growth stands and groves, 200 years of age, relics of a distant era of forest fire and other conditions favourable to hemlock regeneration. Eastern hemlock is a species of great longevity and the old-growth stands are not considered to be in danger of breakup in the foreseeable future if left uncut. The forest floor is usually occupied by sugar maple advance reproduction and by shrubs, most notably hobblebush (Viburnum alnifolium) and striped maple (Acer pennsylvanicum), all of which are browse species for deer. When the hemlock is cut the hardwoods are released to form a hardwood stand with little cover value.

The hemlock is occasionally in demand for sawlogs to produce beams and rough construction lumber but the degree of shake in old-growth timber renders many trees cull. Eastern hemlock is a difficult and expensive species to regenerate and produces a slow-growing tree of low stumpage value to the landowner and of little worth to loggers and dependent mills, therefore no efforts are made to regenerate it following cutting. For all these reasons the hemlock cover type and the winter deer range have been slowly eroded over the years. In 1982 several townships passed a tree-cutting by-law under the Trees Act in reaction to public opposition to unregulated private land logging. Amongst other things, the bylaw prohibited the logging of hemlock within the Percy Lake yard.

The reaction of the landowners, loggers and local mills to this by-law was relatively mild for predictable reasons. At that time, hemlock was in low demand for logs and remains so. Hemlock is being generally bypassed in current operations and where cut, brings in low stumpage. In short, the timber resource users have yet to be hurt.

One landowner, who holds a 25 000-acre (910 000-ha) tract for timber production, objected to the bylaw on the grounds that it limited his future opportunities and amounted to expropriation without compensation. He preferred to cut the hemlock when it was profitable to do so and to allow the stand to convert to the associated hardwood species, which have a faster rate of growth and higher value. His conclusions have a sound forestry basis.

The real test for the local deer herd, especially for those that winter outside of the Percy yard, will come if hemlock stumpage values should rise in the future. 